Portland State University

PDXScholar

\title{
Variation in the Response of Crustacean
}

Zooplankton Species Richness and Composition to the Invasive Predator Bythotrephes Longimanus

\author{
Angela L. Strecker \\ Portland State University, angela.strecker@wwu.edu \\ Shelley E. Arnott \\ Queen's University - Kingston, Ontario \\ Norman D. Yan \\ York University \\ Robert Girard \\ Ontario Ministry of the Environment
}

Follow this and additional works at: https://pdxscholar.library.pdx.edu/esm_fac

Part of the Environmental Sciences Commons, and the Terrestrial and Aquatic Ecology Commons Let us know how access to this document benefits you.

\section{Citation Details}

Strecker, Angela L.; Arnott, Shelley E.; Yan, Norman D.; and Girard, Robert, "Variation in the Response of Crustacean Zooplankton Species Richness and Composition to the Invasive Predator Bythotrephes Longimanus" (2006). Environmental Science and Management Faculty Publications and Presentations. 47.

https://pdxscholar.library.pdx.edu/esm_fac/47

This Post-Print is brought to you for free and open access. It has been accepted for inclusion in Environmental Science and Management Faculty Publications and Presentations by an authorized administrator of PDXScholar. Please contact us if we can make this document more accessible: pdxscholar@pdx.edu. 
3 Variation in the response of crustacean zooplankton species richness and

4 composition to the invasive predator Bythotrephes

5

6 Angela L. Strecker*, Shelley E. Arnott

7 Department of Biology, Queen's University, Kingston, ON, Canada, K7L 3N6

$8 \quad$ Email: strecker@biology.queensu.ca, arnotts@biology.queensu.ca

9 Norman D. Yan

Biology Department, York University, Toronto, ON, Canada, M3J 1P3 and Dorset Environmental Science Centre, Ontario Ministry of the Environment, Dorset, ON, Canada, P0A 1E0

Email: nyan@yorku.ca

14 Robert Girard Dorset Environmental Science Centre, Ontario Ministry of the Environment, Dorset, ON, 16 Canada, P0A 1E0 Email: robert.girard@ene.gov.on.ca

$19 *$ Corresponding author:

20 Department of Biology, Queen's University, Kingston, ON, Canada, K7L 3N6

21 Email: strecker@biology.queensu.ca

22 Phone: (613) 533-6000 x78493

23 Fax: (613) 533-6617 


\section{Abstract}

25 The predacious invertebrate Bythotrephes longimanus has now invaded $>90$ freshwater lakes in

26 North America. There is some evidence that Bythotrephes has a negative effect on summer

27 zooplankton species richness; however, no study has examined the effect of Bythotrephes

28 throughout the ice-free season in more than one lake. We visited ten invaded and four reference

29 lakes every two weeks from May to September, collecting Bythotrephes, crustacean zooplankton,

30 and water chemistry samples. Composite samples were pooled across the study season for each

31 lake. Bythotrephes significantly reduced cladoceran species richness, diversity, and abundance,

32 and the total zooplankton community also exhibited decreased richness, diversity, and

33 abundance. Seasonal sampling was better than synoptic surveys at detecting changes in

34 abundance, but richness estimates were similar. As Bythotrephes continues to spread across lake

35 landscapes, we expect it will have profound impacts on local and regional richness and species

36 distribution patterns.

37

38 Keywords: Bythotrephes, zooplankton, species richness, boreal shield lakes, invasive species 


\section{Introduction}

Bythotrephes longimanus Leydig (Crustacea, Onychopoda) is a predatory zooplankton

44 species that has invaded numerous lakes in North America. First detected in Lake Ontario in 1982 (Mills et al. 2003), Bythotrephes has spread to all of the Laurentian Great Lakes and $>90$

46 inland lakes in Ontario (C. Gamble, Ontario Federation of Anglers and Hunters, 4601 Guthrie

47 Dr., Peterborough, ON K9J 8L5, Canada, unpubl. data), Minnesota (M. Brown, Department of 48 Biology, University of Minnesota-Duluth, Duluth, MN 55812, USA, unpubl. data), Michigan

49 (Jarnagin et al. 2000), and reservoirs in Ohio (Ferry and Wright 2002). Bythotrephes occupies

50 lakes that span a gradient of temperature, salinity, $\mathrm{pH}$, and depth within its native range in

51 Eurasia (Grigorovich et al. 1998). Humans are an important dispersal vector for Bythotrephes,

52 and with its broad tolerance of environmental conditions, it appears that it has the potential to

53 invade a large number of lakes in North America (MacIsaac et al. 2000; 2004).

Our understanding of the impacts of Bythotrephes on inland aquatic communities in

55 North America is incomplete. Invasion events are unpredictable, thus little empirical data documenting the effects of invasion on recipient communities exists. However, a single case

57 study of long-term biweekly records of both pre- and post-invasion planktonic communities from

58 Harp Lake, Ontario has revealed evidence of negative effects of Bythotrephes on crustacean

59 zooplankton species richness and cladoceran zooplankton abundance since its invasion in 1993

60 (Yan et al. 2001; 2002).

Although trends seen in Harp Lake suggest that the invasion of Bythotrephes will have

62 important consequences for zooplankton communities, effects of predation can be site-specific

63 (Posey and Hines 1991). Broader spatial surveys are necessary to determine how universal the

64 impacts of Bythotrephes are in temperate lakes. A study comparing 17 invaded boreal shield

65 lakes to 13 uninvaded reference lakes provided strong evidence that the patterns of invasion 
observed in Harp Lake were also expressed in other lakes of differing water chemistry,

67 morphometry, and species assemblages (Boudreau and Yan 2003). However, sampling for this

68 study was limited to a single mid-summer vertical zooplankton haul, which can underestimate

69 the annual species pool by 50\% (Arnott et al. 1998). As well, Bythotrephes abundances

70 generally peak in mid-summer in boreal lakes (J. Young and E. Parrott, Department of Biology,

71 York University, Toronto, Ontario, Canada, M3J 1P3, Canada, unpubl. data); however, they tend

72 to be absent from the pelagic zone in the early and latter months of the ice-free season. If some

73 zooplankton species are able to take advantage of vernal and autumnal temporal refuges that

74 exist when Bythotrephes are rare or absent from the water column, then Boudreau and Yan

75 (2003) may have overestimated the effect of Bythotrephes on annual zooplankton species pools.

76 For example, some copepods may change the timing of reproduction in order to reduce overlap

77 with predators which peak later in the summer (Hairston Jr. and Walton 1986), and Daphnia

78 clones have exhibited earlier age at maturation in the presence of fish kairomones (Sakwińska

79 2002).

The primary objective of this study was to examine the effects of Bythotrephes on ice-

81 free season averages of species richness, diversity, evenness, and abundance of crustacean

82 zooplankton in boreal shield lakes. We expected that Bythotrephes would cause declines in all

83 these indices of community structure. However, because of the inclusion of time periods when

84 Bythotrephes were absent from the water column, there may be temporal refuges available for

85 some species, during which time they might prosper. We used the persistence of Bythotrephes in

86 the water column of our study lakes as a way to assess the availability of a temporal refuge for

87 zooplankton. Therefore, high persistence would suggest that there is a short time available for

88 zooplankton to avoid Bythotrephes and that we would expect to see greater negative effects as

89 compared to low persistence of the invader, where zooplankton would have an opportunity to 
90 survive in the absence of predation by this invertebrate. Hence, our seasonal purview might

91 actually detect reduced effects in comparison with those observed during peak Bythotrephes

92 abundance (Boudreau and Yan 2003; Barbiero and Tuchman 2004), or indeed no effects at all.

93 A secondary objective of this study was to assess the relationship between species

94 richness and several environmental factors that are typically related to the number of crustacean

95 zooplankton species in a lake. In general, species richness is positively related to lake area

96 (Dodson 1992), and has a hump-shaped relationship with lake productivity (Dodson et al. 2000).

97 In addition, invertebrate predators have been shown to be important in structuring zooplankton

98 communities. In a survey of 60 lakes on the Precambrian Shield, Keller and Conlon (1994)

99 found that a number of zooplankton species common to the region, such as Daphnia galeata

100 mendotae and Diaphanosoma birgei, were completely absent from fishless lakes containing the

101 phantom midge larvae, Chaoborus americanus, a factor attributed to invertebrate predation.

102 Although our lakes were not chosen to span large gradients of area or productivity, we believe

103 that Bythotrephes may alter these conventional relationships and will be an important driver of

104 ecosystem change.

\section{Materials and methods}

106 Twenty lakes in the districts of Muskoka, Haliburton, and Parry Sound in south central

107 Ontario, Canada were chosen for the survey. The lakes are oligo- to mesotrophic and

108 circumneutral in $\mathrm{pH}$, as is typical of many boreal shield lakes (Table 1). All of the study lakes

109 have forested catchments (mixed deciduous and coniferous), small littoral zones, and are used

110 primarily for recreation. Lake herring (Coregonus artedii), rainbow smelt (Osmerus mordax),

111 lake whitefish (Coregonus clupeaformis), and yellow perch (Perca flavescens) are the primary

112 planktivorous fish in these lakes (Ontario Ministry of Natural Resources: S. Scholten and E.

113 McIntyre, District of Parry Sound, Parry Sound, ON P2A 1S4, Canada, and S. Sandstrom, 
114 District of Muskoka, Bracebridge, ON P1L 1W9, Canada, unpubl. data). All the study lakes

115 were chosen to have a similar glacial history and therefore, there were equal probabilities of

116 including zooplankton species dispersed by glacial retreat. Although our intention was to have

117 equal numbers of invaded and reference lakes, Bythotrephes was detected in six of our planned

118 reference lakes reducing their number to four. Hence, we reported results from 14 study lakes -

119 ten invaded and four reference.

120 Crustacean zooplankton were sampled every two weeks from May to September 2003 ( $n$

$121=9$ ) at a deep hole in each lake, located each time using GPS. Sample volume varied slightly

122 among dates because of small differences in station depth (Table 1). A single zooplankton

123 sample was taken by pulling a conical net with a $110 \mu \mathrm{m}$ mesh size and $0.5 \mathrm{~m}$ diameter through

124 the water column, starting $5 \mathrm{~m}$ off the lake bottom. Samples were preserved in $5.5 \%$ sugared and

125 buffered formalin and following preservation, a seasonal composite sample was obtained by

126 combining equal proportions from each of the nine biweekly zooplankton samples. Rotifers

127 were sampled from the epilimnion in a concurrent study with a $2 \mathrm{~cm}$ diameter vertical tube

128 sampler (Hovius et al. 2006). On each sampling date, Bythotrephes was sampled at five stations

129 in each lake, including the deep hole, with a conical net of $400 \mu \mathrm{m}$ mesh size and $0.5 \mathrm{~m}$

130 diameter. The stations were $<1 \mathrm{~km}$ apart. A single haul was taken at each station from $5 \mathrm{~m}$ off

131 the lake bottom to the water surface. Mean ice-free Bythotrephes abundance in the ten invaded

132 lakes was estimated by averaging Bythotrephes abundance in the five replicate hauls in each lake

133 over eight sampling dates from June to September 2003. Only eight dates were used as

134 Bythotrephes samples were not taken in May. The number of sampling dates that Bythotrephes

135 was present and its persistence in invaded lakes are described in Table 2. Persistence was

136 defined as the number of consecutive sampling dates that Bythotrephes abundance in the lake

137 was $>5$ individuals $\cdot \mathrm{m}^{-3}$. It has been suggested that there may be an effect threshold of 
138 Bythotrephes at abundances of 3-5 individuals $\cdot \mathrm{m}^{-3}$, especially with regards to their main prey,

139 cladocerans (Boudreau and Yan 2003). The higher threshold value (5 individuals $\left.\cdot \mathrm{m}^{-3}\right)$ was

140 chosen as it is a more conservative estimation of Bythotrephes effects on the zooplankton

141 community.

142 Zooplankton were enumerated using a protocol designed to ensure reasonable

143 representation of rare species (Girard and Reid 1990). Subsamples were generated with a

144 Folsom plankton splitter, and a mean of 336 individuals (standard deviation $=109$ ) were

145 enumerated. The remainder of the sample was scanned for rare species. Juvenile copepods were

146 excluded from all analyses, except total abundance. Zooplankton were identified and counted on

147 a Leica MZ 12.5 dissecting microscope. Because of uncertainty in identification, Bosmina

148 (Bosmina) freyi and Bosmina (Bosmina) liederi (Taylor et al. 2002) were pooled, as were

149 Chydorus sphaericus and C. brevilabris (Frey 1980). Taxonomic revisions are listed in Table

$150 \mathrm{~S} 1$.

151 Water chemistry samples were taken the week of 14 July 2003. An integrated tube

152 sampler (1 $\mathrm{cm}$ diameter) was used to collect water from the epilimnion, which was filtered

153 through $80 \mu \mathrm{m}$ mesh to remove large particles, especially zooplankton. Calcium, dissolved

154 organic carbon (DOC), conductivity, $\mathrm{pH}$, and total phosphorus (TP) were analyzed following

155 Ontario Ministry of the Environment (1983) protocols (Table 1). Chlorophyll $a$ (chl $a$ ) samples

156 were collected every two weeks by concentrating a known volume of epilimnetic water onto a

$157 \quad 0.7 \mu \mathrm{m}$ glass fibre filter, extracting for $24 \mathrm{~h}$ in methanol, and analyzing with a TD 700

158 Fluorometer (Table 2) (Turner Designs, Sunnyvale, California, USA) (Welschmeyer 1994).

159 We used two methods to assess the adequacy of our zooplankton richness estimates.

160 First, we compared observed species richness, the number of species found in the composite

161 sample, to Chao's index $\left(S_{C h a o 1}\right)$, a non-parametric measure that is recommended for estimating 
162 species richness, as it does not require knowledge of the species abundance distribution

163 (Magurran 2004). $S_{\text {Chao } 1}$ was calculated by

164

(1) $S_{\text {Chaol }}=S_{o b s}+\frac{F_{1}^{2}}{2 F_{2}}$

165 where $S_{o b s}$ is the number of species observed in the sample, $F_{1}$ is the number of species in the

166 sample that are represented by a single individual, and $F_{2}$ is the number of species that are

167 represented by two individuals (Chao 1984). This estimator will exceed observed species

168 richness as the relative frequency of singletons increases, providing an estimate of total richness

169 based on the chance that some rare species might be missed (Magurran 2004). The second

170 approach to assessing our richness estimates was to determine if our counting effort was

171 sufficient to sample all species present by examining the relationship between number of

172 individuals counted and richness. The difference in species richness using Chao's index was

173 negligible $(t=-0.05, p=0.96)$, as was the relationship between number of individuals counted

174 and richness $\left(r^{2}=0.10, p=0.29\right)$, suggesting that our observed richness is probably

175 representative of the number of crustacean zooplankton species in the pelagic region of the lakes.

176 Bythotrephes was not included in richness estimates.

177 Species diversity and evenness were assessed using the Shannon-Wiener diversity index

178 and Smith and Wilson's (1996) evenness index, $E_{\mathrm{var}}$, respectively. The values of $E_{\mathrm{var}}$ fall

179 between 0 (minimum evenness) and 1 (maximum evenness),

180

$$
E_{\mathrm{var}}=1-\left(\frac{2}{\pi \arctan \left\{\sum_{i=1}^{S}\left(\ln n_{i}-\sum_{j=1}^{S} \ln n_{j} / S\right)^{2} / S\right\}}\right)
$$


181 where $n_{i}=$ number of individuals of species $i, n_{j}=$ number of individuals of species $j$, and $S=$

182 total number of species. $E_{v a r}$ is recommended as the best evenness measure for general use

183 (Smith and Wilson 1996).

184 Multivariate ordination techniques were used to evaluate species abundances in relation 185 to environmental variables and the presence of Bythotrephes. A preliminary examination using 186 correspondence analysis suggested that linear ordination analysis was appropriate, thus 187 redundancy analysis (RDA) was performed using Canoco 4.5 (ter Braak and Šmilauer 2002). 188 Bythotrephes was entered as a categorical variable to maximize differences between the levels of 189 the treatments. Environmental variables were assessed for collinearity if the variance inflation 190 factor was $>10$ (Quinn and Keough 2002). All of the significant predictors were independent. 191 All species represented by adults were included in the analysis, and abundances were log192 transformed to reduce the influence of dominant species. Forward selection identified the 193 variables that explained the most variance in species data, which were then tested for 194 significance using a Monte Carlo permutation test (499 permutations).

195 Multiple regression analyses were performed to determine what proportion of the 196 variation in species richness data could be explained by Bythotrephes abundance and persistence, 197 presence/absence of dominant planktivorous fish species, and by environmental variables (i.e., $198 \mathrm{TP}, \mathrm{pH}$, maximum depth, and lake area), using the best subsets procedure (StatSoft 2001).

199 Planktivorous fish data was provided from sampling by the Ontario Ministry of Natural

200 Resources, but because of uncertainty in quantifying fish abundance, the major planktivores were 201 placed in categories of abundance (Table 2). For the multiple regression analysis, abundances 202 were converted to categorical numerical values, e.g. absent $=0$, absent/once present $=0$, very 203 low $=1$, low $=2$, medium $=3$, high $=4$, and averaged for each lake to create an index of fish 204 density. Yellow perch could only be classed as present or absent, and as they were present in all 
205 lakes, they were excluded from analyses. Collinearity of environmental predictor variables was

206 detected if the variance inflation factor of any predictors was $>10$ (Quinn and Keough 2002).

207 Chl $a$ was removed from the analysis due to collinearity with TP. Assumptions of normality,

208 heterogeneity of variance, and independence were also assessed. The best models were chosen

209 by using several criteria: adjusted $r^{2}$, Mallow's $C_{p}$, and Akaike's information criterion (AIC)

210 (Quinn and Keough 2002). When evaluating the models, smaller values of Mallow's $C_{p}$ and

211 AIC indicate the best fit.

\section{Results}

213 Physical and chemical characteristics did not differ between invaded and uninvaded

214 lakes, with the exception of total phosphorus and chl $a$, which were, on average, $3.33 \mu \mathrm{g} \cdot \mathrm{L}^{-1}$ and

$2150.94 \mu \mathrm{g} \cdot \mathrm{L}^{-1}$ greater in the uninvaded lakes, respectively (TP: $t=-2.45, p=0.03$; $\operatorname{chl} a: t=-4.83$,

$216 p<0.01)($ Table 1,2). There were no significant differences between invaded and uninvaded

217 lake calcium $(\log (\mathrm{x}+1)$-transformed), DOC, conductivity, and $\mathrm{pH}$ (Table 1). There was also no

218 difference in general lake morphometry, as both maximum depth $\left(Z_{\max }\right)$ and surface area $(\log$

$219(\mathrm{x}+1)$-transformed) were similar between lake categories (Table 1).

220 In comparisons of invaded and non-invaded lakes, we found that there was a large

221 reduction in observed species richness of zooplankton taxa in invaded lakes, from an average of

22215.0 in uninvaded lakes down to 11.6 species in invaded lakes $(t=-2.12, p=0.06)$ (Fig. 1). This

223 decline was largely due to changes in cladoceran zooplankton, which decreased on average by

224 four taxa in invaded lakes $(t=-3.28, p<0.01)$ (Fig. 1). Copepod richness was similar in invaded

225 and reference lakes $(t=0.76, p=0.46)$ (Fig. 1). There was no difference in Shannon-Wiener

226 diversity in total zooplankton $(t=-1.31, p=0.22)$ and copepods $(t=-0.40, p=0.70)$ in invaded

227 lakes compared to the uninvaded lakes, but there was a significant reduction in the diversity of

228 cladoceran zooplankton $(t=-2.17, p=0.05)$ (Fig. 1). Evenness of the total zooplankton 
community $(t=0.40, p=0.70)$ was unaffected by Bythotrephes invasion, while cladocerans

230 experienced a slight increase with invasion $(t=1.89, p=0.08)$, and copepods showed a slight

231 decrease in the Bythotrephes lakes $(t=-1.89, p=0.08)$ (Fig. 1). Invasion had a negative effect

232 on overall zooplankton $(t=-1.91, p=0.08)$ and copepod abundance $(t=-1.91, p=0.08)$,

233 resulting in a 2 -fold difference for both groups. In addition, there was a decline in cladoceran

234 abundance in invaded lakes $(t=-2.86, p=0.01)$, where an almost 4-fold difference was observed 235 (Fig. 1).

236 The relationship between Bythotrephes abundance and zooplankton species richness and

237 abundance was inconsistent across the invaded study lakes (Fig. 2). The deviations in species

238 richness and abundance from the reference lake condition generally increased with higher

239 abundances of Bythotrephes, but some invaded lakes actually had greater richness and

240 abundance than uninvaded lakes. When we explicitly considered changes in zooplankton

241 communities relative to the abundance of Bythotrephes in the lakes using linear regression, we

242 found that crustacean zooplankton species richness $\left(r^{2}=0.04, p=0.52\right)$, diversity $\left(r^{2}<0.01, p=\right.$

$2430.93)$, and abundance $\left(r^{2}=0.06, p=0.42\right)$ were not related to the mean abundance of

244 Bythotrephes. Likewise, cladoceran species richness $\left(r^{2}=0.13, p=0.20\right)$, diversity $\left(r^{2}=0.11, p\right.$

$245=0.26)$, and abundance $\left(r^{2}=0.15, p=0.14\right)$ were not related to mean Bythotrephes abundance.

246 Interestingly, it seems that Bythotrephes had a negative effect on both species richness and

247 diversity when its mean abundance was $<4$ individuals $\cdot \mathrm{m}^{-3}$, but above this threshold, the effect

248 is less clear.

249 RDA captured a significant amount of variance $(p<0.01)$ in zooplankton species

250 abundances, with Bythotrephes presence/absence explaining 43\% of total species variation, and $251 \mathrm{Z}_{\max }(22 \%), \operatorname{chl} a(20 \%)$, and TP (15\%) contributing to the remainder of species abundance

252 variation (Fig. 3). The first axis $\left(\lambda_{1}=0.22, p=0.03\right)$ contrasts the presence with the absence of 
253 Bythotrephes, as most of the invaded lakes fall on the same side as the Bythotrephes vector, and

254 all of the reference lakes are on the opposite side of the gradient. A number of species were

255 negatively associated with the invader (e.g., Diaphanosoma birgei, Mesocyclops edax,

256 Holopedium gibberum), and only one species, the glacial relict Senecella calanoides, was

257 positively correlated with Bythotrephes presence. The second axis $\left(\lambda_{2}=0.10\right)$ seems to be related

258 to lake productivity, as some cladoceran taxa (Bosmina (Bosmina) spp., Daphnia retrocurva, and

259 D. birgei) and omnivorous cyclopoids (Mesocyclops edax and Orthocyclops modestus) were

260 positively associated with the TP and chl $a$ vectors.

261 The majority of zooplankton taxa were, on average, in lower abundance in invaded lakes

262 than in reference lakes (Fig. 4). The cladoceran taxa tended to fall further below the 1:1 line than

263 did the copepods, especially smaller-bodied taxa such as Chydorus spp. and Eubosmina

264 coregoni. A few larger taxa, such as Senecella calanoides, Cyclops scutifer, and Daphnia dubia,

265 were more abundant in invaded lakes than reference lakes, on average, but for the most part, both

266 large and small-bodied zooplankton were less abundant in Bythotrephes-invaded lakes.

267 Species richness tended to increase with longer persistence times of Bythotrephes

268 populations throughout the summer $\left(r^{2}=0.31, p=0.09\right)$, suggesting that there is no temporal

269 refuge available to zooplankton. Using multiple regression analysis we found that all of the most

270 parsimonious models to explain species richness had negative associations of species richness

271 with mean Bythotrephes abundance, but that zooplankton richness was positively related to

272 Bythotrephes persistence in high abundances in the lake (Table 3). In both models, species

273 richness was positively related to duration of Bythotrephes persistence and TP, and negatively

274 related to mean Bythotrephes abundance. In addition, the best model selected by AIC had

275 positive associations of zooplankton richness with area and $\mathrm{pH}$. The presence of fish planktivore

276 species had no effect on zooplankton species richness. 


\section{Discussion}

Our study has demonstrated that Bythotrephes can have negative effects on zooplankton communities through parts of the ice-free season, reducing species richness, diversity, and

280 abundance throughout the ice-free season. This negative effect was exacerbated in the

281 cladocerans, which showed significant declines in richness (on average four less species in

282 invaded lakes), abundance (a 4-fold decline), and diversity. These results are in agreement with

283 the declines in zooplankton richness observed in Harp Lake (Yan et al. 2002), Muskoka lakes

284 (Boudreau and Yan 2003), and lakes Michigan, Erie, and Huron (Barbiero and Tuchman 2004)

285 (Table 4). Reductions in the abundance of zooplankton have been shown experimentally

286 (Strecker and Arnott 2005) and in Harp Lake (Yan et al. 2001); however, some recent studies

287 have failed to detect changes in total zooplankton community abundance (Boudreau and Yan

288 2003; Barbiero and Tuchman 2004) (Table 4). The samples in Boudreau and Yan's (2003) study

289 were taken on a single sampling date, and this snapsnot approach doesn't take in account 290 seasonal dynamics, as was done in our study and Yan et al. (2001). Barbiero and Tuchman's

291 (2004) samples were only taken for one month starting 1 August, and thus, do not reflect

292 zooplankton abundance in late spring, early summer, and fall. A comparison of our study with

293 others over a shorter period of time suggests that short-term synoptic surveys may adequately

294 document changes in some measures of zooplankton community structure associated with

295 Bythotrephes invasion. For example, the effect of Bythotrephes on species richness seems to be

296 consistent between different sampling routines, but longer studies, especially in smaller inland

297 lakes, that encompass the entire season seem to capture changes in total abundance better than 298 single sampling dates (Table 4).

299 Several zooplankton taxa showed steep declines in Bythotrephes-invaded lakes. As past 300 studies have documented the general negative effect that Bythotrephes has on many cladoceran 
301 taxa (Boudreau and Yan 2003), we expected to observe this in our study as well. As expected,

302 the abundances of a number of common cladoceran species, such as Bosmina (Bosmina) spp. and

303 D. birgei, were severely reduced: on average, a decrease of $>4$ times in invaded lakes. The

304 larger species Daphnia longiremis, Daphnia mendotae, and Holopedium gibberum also had

305 lower abundances in invaded lakes, suggesting that body size alone does not provide refuge from

306 predation. As well, it appears as though some hypolimnetic species, such as $D$. longiremis

307 (Keller and Conlon 1994), do not escape predation. These patterns are generally in agreement

308 with Boudreau and Yan (2003), Yan et al. (2001), and Barbiero and Tuchman (2004), although

309 there seem to be some system-specific differences. For example, D. mendotae has remained

310 unaffected by Bythotrephes in Harp Lake (Yan et al. 2001, Boudreau and Yan 2003, and this

311 study), but has declined in other lakes (Barbiero and Tuchman 2004). Unexpectedly, several

312 common copepod taxa (Leptodiaptomus minutus, Diacyclops bicuspidatus thomasi, and

313 Mesocyclops edax) in our study were also negatively affected by Bythotrephes. Previously, only

314 Mesocyclops edax was thought to be affected by invasion (Boudreau and Yan 2003; Barbiero

315 and Tuchman 2004). Given that copepods are in high abundance in the late spring in these lakes,

316 before Bythotrephes emerges from resting eggs and rapidly builds up populations through

317 parthenogenic reproduction (A. Strecker, unpubl. data), it is especially surprising that they

318 declined, as their earlier dominance in lakes would suggest that they should be able to use a

319 temporal refuge from Bythotrephes predation. However, longer-lived slow-reproducing

320 copepods may actually be more susceptible to predation by Bythotrephes because they are unable

321 to reproduce as quickly as cladocerans. Thus, the copepods are less able to respond to low

322 predator abundances, as Bythotrephes is known to have extremely patchy spatial and temporal

323 dynamics (J. Young and E. Parrott, Department of Biology, York University, Toronto, Ontario,

324 Canada, M3J 1P3, Canada, unpubl. data), and therefore, cannot take advantage of this window of 
opportunity. This further supports the notion that to adequately assess changes in total and

326 individual zooplankton abundances resulting from Bythotrephes invasion, longer-term surveys

327 are necessary.

328 Our study suggests that most species are not able to take advantage of a temporal refuge

329 from Bythotrephes predation. We found that longer persistence times of Bythotrephes resulted in

330 higher species richness, the opposite of what we would expect to see if a temporal refuge was

331 indeed available. Bythotrephes was detected in invaded lakes on an average of seven sampling

332 dates, or about 14 weeks during the summer. This is likely a conservative estimate, as

333 Bythotrephes was present in $90 \%$ of invaded lakes on the final sampling date in September, and

334 has shown the ability to persist into late fall in some lakes (J. Young, Department of Biology,

335 York University, Toronto, Ontario, Canada, M3J 1P3, Canada, pers. comm). Thus, in most

336 lakes, the only opportunity for a temporal refuge is in the spring, and our evidence suggests that

337 this window of opportunity is not being used by zooplankton, perhaps because water

338 temperatures are cool and food availability is low in these oligo-mesotrophic lakes. If

339 zooplankton were indeed using this temporal refuge, we would expect to see no effect of

340 Bythotrephes on zooplankton richness and abundance, especially on copepods, which are

341 typically in high numbers in these lakes in late spring, thus having reduced temporal overlap with

342 the invader. However, this was not the case: overall zooplankton abundance and richness were

343 reduced, and several copepod taxa were also negatively affected by Bythotrephes. Another

344 potential explanation is that there are competitive interactions occurring between Bythotrephes

345 and its predators. Mysis relicta and other zooplanktivores may benefit from longer Bythotrephes

346 persistence times by switching from smaller zooplankton to the larger invader, thus freeing the

347 zooplankton from intense predation. Gut content analysis of M. relicta collected from several of 
348 our study lakes has revealed the presence of Bythotrephes body parts, thus it seems that the

349 invader can also be a prey item for other invertebrate predators (Nordin 2005).

350 There was a substantial amount of among-lake variation in the responses of the

351 zooplankton communities to Bythotrephes invasion. This variability appears to be unrelated to

352 the actual abundance of Bythotrephes, which was not a strong predictor of zooplankton richness

353 or abundance in invaded lakes. There is some evidence that zooplankton can adapt their

354 morphologies in the presence of Bythotrephes (Bungartz and Branstrator 2003), suggesting that

355 the abundance of the invader may play a role in eliciting behavioural and morphological

356 responses in the zooplankton community, and thus increasing species survival. Two of the

357 invaded lakes, Peninsula and Vernon, had zooplankton communities that more closely resembled

358 communities in non-invaded reference lakes. Both lakes had relatively high mean Bythotrephes

359 abundance (7.8 and 4.3 individuals $\cdot \mathrm{m}^{-3}$, respectively), and had richness values that fall more into

360 the range of uninvaded lakes. When these lakes were excluded from regression analyses, mean

361 Bythotrephes abundance had a significant negative effect on species richness $\left(r^{2}=0.53, p<\right.$

362 0.01). The redundancy analysis also suggests that Peninsula and Vernon lakes have species

363 compositions that are more similar to reference lakes than to invaded lakes. We are unsure why

364 the zooplankton community composition of these two lakes is seemingly unaffected by invasion.

365 One possibility is that Bythotrephes is feeding in a density-dependent manner, reducing the

366 abundances of certain preferred species to low densities, and then switching to higher density

367 prey items that can be caught more easily. Thus, Bythotrephes is not reducing any species to the

368 point where it can no longer be detected. Consistent with this hypothesis, the evenness of

369 Peninsula and Vernon lakes was higher than the average of the invaded lakes, and the diversity

370 was greater than the average diversity of the uninvaded lakes. The abundances of the

371 zooplankton communities of both of these lakes is below the average of other invaded lakes, so 
372 while it seems that Bythotrephes is reducing zooplankton abundance, species richness remains

373 unaffected. However, if Bythotrephes feeding is indeed density dependent in these lakes, then

374 why is this not occurring in all of the invaded lakes? It is possible that zooplankton reproduction

375 in these lakes was high enough to fend off the loss of species richness. Yan et al. (1991) showed

376 that for the rotifer, Keratella taurocephala, high rates of production could be maintained, even

377 under intense predation by the invertebrate Chaoborus. Vernon Lake had high secondary

378 production relative to Bythotrephes consumption (A. Strecker, unpubl. data), so this may, in part,

379 explain the lack of effect on species richness.

380 Other potential explanations for the high levels of species richness observed in Peninsula

381 and Vernon lakes are that they had different morphological, biotic, and chemical conditions than

382 the rest of the invaded lakes, and thus, there existed some advantage that allowed coexistence.

383 For instance, a deep water spatial refuge in the lake can afford some species a certain amount of

384 protection from predation. However, Peninsula and Vernon lakes were the two shallowest

385 invaded lakes, suggesting that they in fact had a smaller spatial refuge than other invaded lakes.

386 Another possibility is that Peninsula and Vernon lakes were less clear than other invaded lakes,

387 thus offering zooplankton a dark water refuge. This may be the case for Vernon Lake, which

388 had higher DOC and lower Secchi disc values than did other invaded lakes, but not for Peninsula

389 Lake, which had values that were within the range of the other invaded lakes. Thus, this

390 variability that we observed between study lakes in response to an invasion of Bythotrephes may

391 be due to a combination of factors related to characteristics of the invader, i.e., feeding strategy,

392 and to characteristics of the lakes, such as productivity and lake clarity.

393 The importance of lake area and productivity in determining crustacean zooplankton

394 species richness in temperate freshwater lakes has been well-established (Dodson 1992; Dodson

395 et al. 2000). Surface area had little predictive power in our analysis of factors influencing 
species richness in lakes invaded by Bythotrephes, but other variables related to the invader were

397 much better predictors of zooplankton richness. Although we did not measure primary

398 productivity, TP can be used as a surrogate for productivity (see Leibold 1999). A caveat of our

399 study is that uninvaded lakes had slightly higher levels of TP and chl $a$ than did the invaded

400 lakes, but in our oligo-mesotrophic systems, these differences are small, and are unlikely to lead

401 to the observed differences in species richness. In addition, our multiple regression analyses

402 suggest that although TP is an important predictor, Bythotrephes explains far more variation in

403 species richness. Although Bythotrephes abundance by itself was a poor predictor of species

404 richness, when combined with persistence of the invader in multiple regression analysis, the

405 explanatory power of the two variables was much greater. It is possible that the result from the

406 linear regression was being influenced by the two outlier values, Vernon and Peninsula Lakes,

407 while these values became less important with more predictive variables. In fact, neither of these

408 values had an exceptionally large influence on the final multiple regression models, as measured

409 by Cook’s distance statistic (Quinn and Keough 2002).

410 The composition of the fish community can also have substantial effects on the structure

411 of the zooplankton community (Brooks and Dodson 1965). While there appear to be some

412 differences in the abundance of planktivores present in invaded versus reference lakes, our data

413 suggest that Bythotrephes is still having a substantial negative effect. If fish were in fact

414 responsible for the effects that we observed, then we would expect larger zooplankton species to

415 be more negatively affected than small taxa. However, reductions in species richness were

416 proportionately greater for small species (28\%) than for large-bodied zooplankton (14\%), which

417 supports our assertion that Bythotrephes is largely responsible for the observed reduction in

418 zooplankton species richness. Other variables, such as pH (Keller and Pitblado 1984), calcium

419 (Schell et al. 2001; Wærvågen et al. 2002), and post-glacial history of the lake (Dadswell 1974; 
420 Carter et al. 1980) can be important predictors of zooplankton richness. However, neither $\mathrm{pH}$

421 nor calcium were significantly different in Bythotrephes lakes compared to reference lakes, and

422 all of our study lakes have a similar post-glacial history because of the presence of Mysis relicta.

423 Thus, these factors did not influence our results.

424 There is now a significant body of evidence to suggest that Bythotrephes invasions cause

425 changes to the zooplankton communities of freshwater lakes. This is especially true of

426 cladoceran taxa, which seem to take the brunt of Bythotrephes predation, as our study has

427 exhibited striking declines in their richness, abundance, and diversity in invaded lakes. A

428 concurrent study of the rotifer composition and abundance of the same 14 lakes showed a

429 positive relationship between rotifer and Bythotrephes abundance, perhaps as a result of reduced

430 competition with herbivorous cladocerans for phytoplankton prey (Hovius et al. 2006). These

431 results are somewhat surprising, since Bythotrephes is an invertebrate predator that has several

432 native functional analogues in these boreal lakes, including M. relicta, Leptodora kindtii,

433 Chaoborus spp., and water mites (Arachnida, Hydrachnidia). It could be argued that

434 Bythotrephes occupies a unique feeding niche; however, its dietary overlap with other

435 invertebrate predators is high (McNaught et al. 2004; Young and Riessen 2005), and so this

436 seems unlikely. Bythotrephes employs several effective strategies to maintain high feeding rates

437 in these boreal lakes: 1) although it is consumed by some fish species, presumably Bythotrephes'

438 long tail spine decreases predation impact; 2) lack of large amplitude migrations (Yan and

439 Pawson 1997), unlike many other invertebrate predators (Chaoborus, Mysis, Leptodora), so they

440 are continuously in regions of high prey density; 3) parthenogenic reproduction, unlike mites,

441 which are sexual and have slower reproductive times, so they can quickly respond to increases in

442 food resources; and 4) larger neonates, allowing them to exploit a larger range of prey sizes,

443 unlike the small-bodied clutches of Leptodora (Branstrator 2005). What is clear is that not all 
444 lakes respond to Bythotrephes invasion in the same way. Our study has highlighted that there are

445 substantial among-lake differences in the effect of the invader on richness, abundance and

446 diversity of zooplankton communities.

447 As Bythotrephes continues to spread across the landscape of North America, it seems

448 likely that it will be an important new factor in determining the zooplankton composition of

449 freshwater lakes. This is certain to have implications for regional species richness, as our results

450 suggest that certain species, such as the ubiquitous taxa Diaphanosoma birgei and Mesocyclops

451 edax, have reduced abundances in invaded lakes across the landscape, leaving few populations

452 left that may act as sources to disperse to new locales.

\section{Acknowledgements}

454 Funding for this project was provided by Natural Sciences and Engineering Research Council of 455 Canada Discovery Grants to SEA and NDY and Post-Graduate Scholarship to ALS, the 456 Department of Fisheries and Oceans Canada, the Ontario Ministry of the Environment, and 457 Queen's University School of Graduate Studies and Research. We would like to thank the 458 Dorset Environmental Science Centre and its staff, especially Keith Somers, for providing 459 logistical support, water chemistry analyses, and advice. This project benefited from discussions 460 with Ora Johannsson, Michael Arts, Beatrix Beisner, Jon Hovius, Joelle Young, William Taylor, 461 and Lisa Nordin. We are grateful to the Ontario Ministry of Natural Resources for providing fish 462 data. We would also like to thank J. Hovius, Emily Parrott, and Greg Puncher for assistance in 463 the field, and E. Parrott for enumerating the Bythotrephes samples. 
466

467

468

469

470

471

472

473

474

475

476

477

478

479

480

481

482

483

484

485

486

487

488

489

\section{References}

Arnott, S.E., Magnuson, J.J. and Yan, N.D. 1998. Crustacean zooplankton species richness: single- and multiple-year estimates. Can. J. Fish. Aquat. Sci. 55: 1573-1582.

Barbiero, R.P. and Tuchman, M.L. 2004. Changes in the crustacean communities of Lakes Michigan, Huron, and Erie following the invasion of the predatory cladoceran Bythotrephes longimanus. Can. J. Fish. Aquat. Sci. 61: 2111-2125.

Boudreau, S.A. and Yan, N.D. 2003. The differing crustacean zooplankton communities of Canadian Shield lakes with and without the nonindigenous zooplanktivore Bythotrephes longimanus. Can. J. Fish. Aquat. Sci. 60: 1307-1313.

Branstrator, D.K. 2005. Contrasting life histories of the predatory cladocerans Leptodora kindtii and Bythotrephes longimanus. J. Plankton Res. 27: 569-585.

Brooks, J.L. and Dodson, S.I. 1965. Predation, body size, and composition of plankton. Science 150: $28-35$.

Bungartz, B. and Branstrator, D.K. 2003. Morphological changes in Daphnia mendotae in the chemical presence of Bythotrephes longimanus. Arch. Hydrobiol. 158: 97-108.

Carter, J.C.H., Dadswell, M.J., Roff, J.C. and Sprules, W.G. 1980. Distribution and zoogeography of planktonic crustaceans and dipterans in glaciated eastern North America. Can. J. Zoolog. 58: 1355-1387.

Chao, A. 1984. Non-parametric estimation of the number of classes in a population. Scand. J. Stat. 11: 265-270.

Dadswell, M.J. 1974. Distribution, ecology, and postglacial dispersal of certain crustaceans and fishes in eastern North America. National Museum of Natural Sciences Publications in Zoology, No. 11, Ottawa, Ont.

Dodson, S.I. 1992. Predicting zooplankton species richness. Limnol. Oceanogr. 37: 848-856. 
Dodson, S.I., Arnott, S.E. and Cottingham, K.L. 2000. The relationship in lake communities between primary productivity and species richness. Ecology 81: 2662-2679.

Ferry, K.H. and Wright, R.A. 2002. Bythotrephes cederstroemi in Ohio reservoirs: evidence from fish diets. Ohio J. Sci. 102: 116-118.

Frey, D.G. 1980. On the plurality of Chydorus sphaericus (O.F. Müller) (Cladocera, Chydoridae), and designation of a neotype from Sjaelsø, Denmark. Hydrobiologia 69: 83-123.

Girard, R. and Reid, R.A. 1990. Dorset Research Centre study lakes: sampling methodology (1986-1989) and lake morphometry. Ontario Ministry of the Environment. Data Report. Dorset, Ont.

Grigorovich, I.A., Pashkova, O.V., Gromova, Y.F. and van Overdijk, C.D.A. 1998. Bythotrephes longimanus in the Commonwealth of Independent States: variability, distribution, and ecology. Hydrobiologia 379: 183-198.

Hairston Jr., N.G. and Walton, W.E. 1986. Rapid evolution of a life history trait. P. Natl. Acad. Sci. USA 83: 4831-4833.

Hovius, J.T., Beisner, B.E. and McCann, K.S. 2006. Epilimnetic rotifer community responses to Bythotrephes longimanus invasion in Canadian Shield lakes. Limnol. Oceanogr. 51: 1004-1012.

Jarnagin, S.T., Swan, B.K. and Kerfoot, W.C. 2000. Fish as vectors in the dispersal of Bythotrephes cederstroemi: diapausing eggs survive passage through the gut. Freshw. Biol. 43: 579-589.

Keller, W. and Conlon, M. 1994. Crustacean zooplankton communities and lake morphometry in Precambrian Shield lakes. Can. J. Fish. Aquat. Sci. 51: 2424-2434. 
513 Keller, W. and Pitblado, J.R. 1984. Crustacean plankton in northeastern Ontario lakes subjected 514 to acidic deposition. Water Air Soil Poll. 23: 271-291.

515 Leibold, M.A. 1999. Biodiversity and nutrient enrichment in pond plankton communities. Evol. $516 \quad$ Ecol. Res. 1: 73-95.

517 MacIsaac, H.J., Ketelaars, H.A.M., Grigorovich, I.A., Ramcharan, C.W. and Yan, N.D. 2000.

$518 \quad$ Modeling Bythotrephes longimanus invasions in the Great Lakes basin based on its 519 European distribution. Arch. Hydrobiol. 149: 1-21.

520 MacIsaac, H.J., Borbely, J.V.M., Muirhead, J. and Graniero, P.A. 2004. Backcasting and 521 forecasting biological invasions of inland lakes. Ecol. Appl. 14: 773-783.

522 Magurran, A.E. 2004. Measuring biological diversity. Blackwell Publishing, Oxford, UK.

523 McNaught, A.S., Kiesling, R.L. and Ghadouani, A. 2004. Changes to zooplankton community 524 structure following colonization of a small lake by Leptodora kindtii. Limnol. Oceanogr. 49: $1239-1249$.

Mills, E.L., Casselman, J.M., Dermott, R., Fitzsimons, J.D., Gal, G., Holeck, K.T., Hoyle, J.A., Johannsson, O.E., Lantry, B.F., Makarewicz, J.C., Millard, E.S., Munawar, I.F., Munawar, M., O'Gorman, R., Owens, R.W., Rudstam, L.G., Schaner, T. and Stewart, T.J. 2003. Lake Ontario: food web dynamics in a changing ecosystem (1970-2000). Can. J. Fish. Aquat. Sci. 60: 471-490.

Nordin, L.J. 2005. The impact of Bythotrephes longimanus on the diet, growth and energy

534 Ontario Ministry of the Environment. 1983. Handbook of analytical methods for environmental samples. Tech. Rep. Ontario Ministry of the Environment, Laboratory Services and Applied Research Branch, Toronto, Ont. 
Posey, M.H. and Hines, A.H. 1991. Complex predator-prey interactions within an estuarine benthic community. Ecology 72: 2155-2169.

Quinn, G.P. and Keough, M.J. 2002. Experimental design and data analysis for biologists. Cambridge University Press, Cambridge, UK.

541 Sakwińska, O. 2002. Response to fish kairomone of Daphnia galeata life history traits relies on shift to earlier instar at maturation. Oecologia 131: 409-417.

543 Schell, J.M., Santos-Flores, C.J., Allen, P.E., Hunker, B.M., Kloehn, S., Michelson, A., Lillie, R.A. and Dodson, S.I. 2001. Physical-chemical influences on vernal zooplankton community structure in small lakes and wetlands of Wisconsin, U.S.A. Hydrobiologia

Smith, B. and Wilson, J.B. 1996. A consumer's guide to evenness indices. Oikos 76: 70-82.

StatSoft. 2001. STATISTICA 6. StatSoft Inc. Tulsa, Oklahoma.

Strecker, A.L. and Arnott, S.E. 2005. Impact of Bythotrephes invasion on zooplankton communities in acid-damaged and recovered lakes on the Boreal Shield. Can. J. Fish. Aquat. Sci. 62: 2450-2462.

555 ter Braak, C.J.F. and Šmilauer, P. (2002). CANOCO Version 4.5. Biometris - Plant Research

Taylor, D.J., Ishikane, C.R. and Haney, R.A. 2002. The systematics of Holarctic bosminids and a revision that reconciles molecular and morphological evolution. Limnol. Oceanogr. 47: International. Wageningen, The Netherlands.

Wærvågen, S.B., Rukke, N.A. and Hessen, D.O. 2002. Calcium content of crustacean zooplankton and its potential role in species distribution. Freshw. Biol. 47: 1866-1878.

Welschmeyer, N.A. 1994. Fluorometric analysis of chlorophyll $a$ in the presence of chlorophyll $b$ and pheopigments. Limnol. Oceanogr. 39: 1985-1992. 
561 Yan, N.D., Keller, W., MacIsaac, H.J. and McEachern, L.J. 1991. Regulation of zooplankton 562 community structure of an acidified lake by Chaoborus. Ecol. Appl. 1: 52-65.

563 Yan, N.D. and Pawson, T.W. 1997. Changes in the crustacean zooplankton community of Harp 564 Lake, Canada, following invasion by Bythotrephes cederstroemi. Freshw. Biol. 37: 409$565 \quad 425$.

566 Yan, N.D., Blukacz, A., Sprules, W.G., Kindy, P.K., Hackett, D., Girard, R.E. and Clark, B.J. 567 2001. Changes in zooplankton and the phenology of the spiny water flea, Bythotrephes, 568 following its invasion of Harp Lake, Ontario, Canada. Can. J. Fish. Aquat. Sci. 58: 23415692350.

570 Yan, N.D., Girard, R.E. and Boudreau, S. 2002. An introduced invertebrate predator 571 (Bythotrephes) reduces zooplankton species richness. Ecol. Lett. 5: 481-485.

572 Young, J.D. and Riessen, H. 2005. The interaction of Chaoborus size and vertical distribution 573 determines predation effects on Daphnia. Freshw. Biol. 50: 993-1006. 
575 Table 1. Physical and chemical characteristics of study lakes. Standard deviation of mean depth

576 of the composite sample indicated in parentheses. A $t$-test was performed to contrast values in

577 reference and invaded lakes. Lakes sorted by increasing Bythotrephes abundance. $\mathrm{Z}_{\max }=$

578 maximum depth, $\mathrm{DOC}=$ dissolved organic carbon, Cond $=$ conductivity, $\mathrm{TP}=$ total phosphorus.

$\begin{array}{cccccccccc} & \text { N Lat } & Z_{\max } & \text { Composite } & \text { Area } & \text { Calcium } & \text { DOC } & \text { Cond } & & \text { TP } \\ \text { Lake } & \text { W Long } & (\mathrm{m}) & \text { sample mean } & \text { (ha) } & \left(\mathrm{mg} \cdot \mathrm{L}^{-1}\right) & \left(\mathrm{mg} \cdot \mathrm{L}^{-1}\right) & (\mu \mathrm{mhos} \cdot & \mathrm{pH} & \\ & & & \text { depth }(\mathrm{m}) & & & & \left.\mathrm{cm}^{-1}\right) & & \\ \end{array}$

Reference

$45^{\circ} 25^{\prime}$

Buck

23.0

$20.6(1.7)$

656.0

2.6

10.7

25.6

6.33

13.30

$79^{\circ} 23^{\prime}$

$45^{\circ} 32^{\prime}$

Doe

23.

$79^{\circ} 25^{\prime}$

$12.6(1.5)$

1187.0

3.6

7.0

$46.0 \quad 7.08$

12.00

$45^{\circ} 41^{\prime}$

Pickerel

38.

$79^{\circ} 18^{\prime}$

$26.7(1.1) \quad 513.0$

2.8

6.7

32.4

6.82

8.10

$45^{\circ} 37^{\prime}$

Sand

$79^{\circ} 10^{\prime}$

59.0

$37.4(5.3)$

568.2

3.5

6.0

37.2

6.78

7.10

Mean

35.8

$24.3^{*}$

731.1

3.1

7.6

35.3

$6.7510 .13 *$

Invaded

$\begin{array}{ll}\text { Kashaga- } & 44^{\circ} 59^{\prime} \\ \text { wigamog } & 78^{\circ} 36^{\prime} \\ & 45^{\circ} 15^{\prime} \\ \text { Skeleton } & \end{array}$

$79^{\circ} 27^{\prime}$

$39.7 \quad 31.1(0.8)$

817.9

10.8

6.9

$95.4 \quad 7.56$

7.41

$64.7 \quad 53.6(3.3)$

2155.5

3.8

2.6

44.0

6.94

3.82 


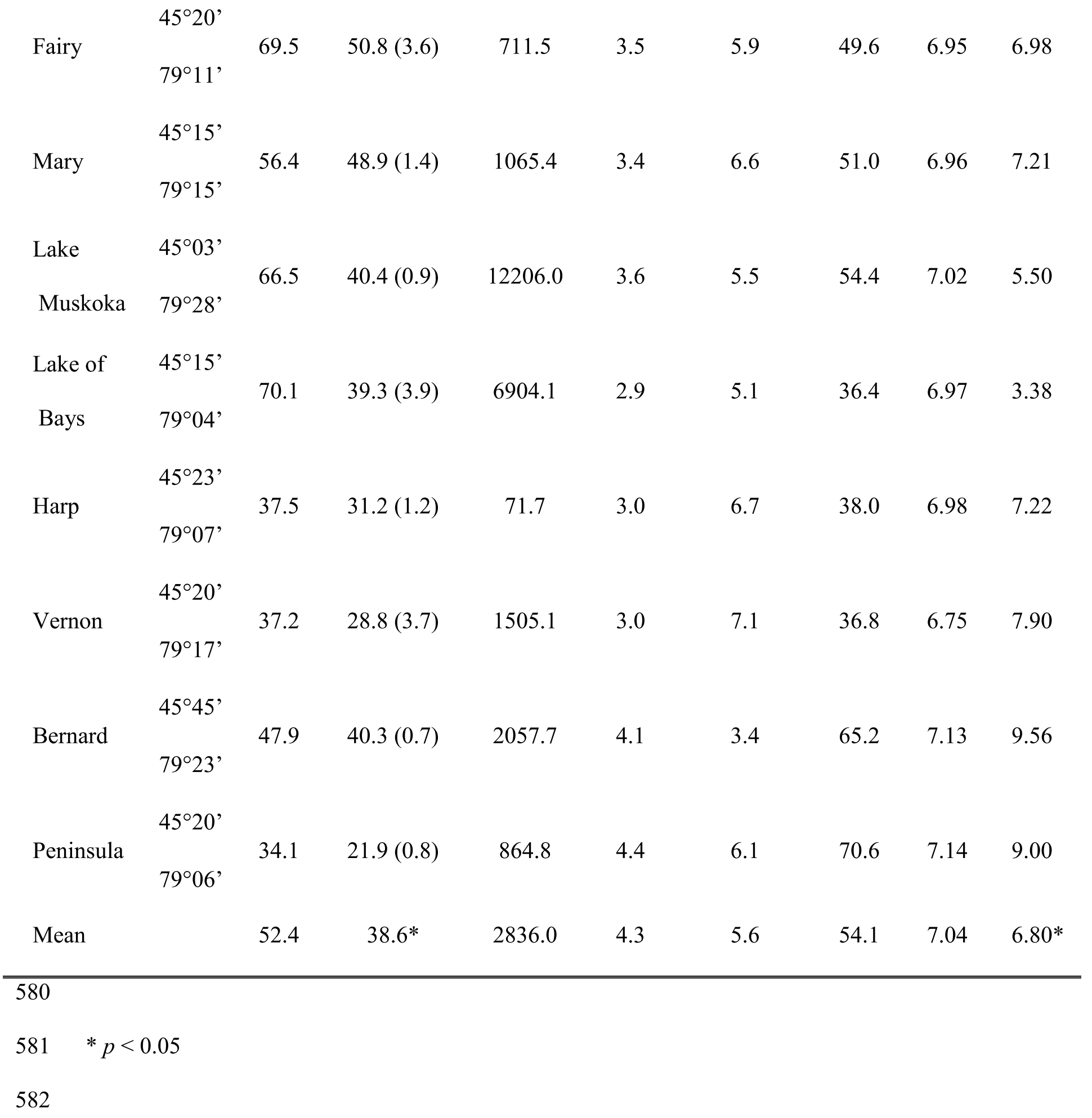


583 Table 2. Biotic characteristics of study lakes. Persistence is defined as number of consecutive

584 sampling dates that Bythotrephes was $>5$ individuals $\cdot \mathrm{m}^{-3}$. Categorical abundance of

585 planktivorous fish provided by Ontario Ministry of Natural Resources (S. Taylor, District of

586 Parry Sound, Parry Sound, ON P2A 1S4, Canada, and S. Sandstrom, District of Muskoka,

587 Bracebridge, ON P1L 1W9, Canada, unpubl. data). A two-tailed $t$-test was performed on chl $a$

588 concentrations in reference and invaded lakes. Lakes sorted by increasing Bythotrephes

589 abundance. $\mathrm{A}=$ absent, $\mathrm{A} / \mathrm{P}=$ absent, but detected in past, $\mathrm{VL}=$ very low, $\mathrm{L}=$ low, $\mathrm{M}=$

590 medium, $\mathrm{H}=$ high, $\mathrm{N} / \mathrm{A}=$ not available, $\mathrm{P}=$ present.

\begin{tabular}{cccccccc}
\hline \hline & Mean & Sample dates & Persistence & & & & \\
Lake & chl $a$ & Bythotrephes & of & Lake & Rainbow & Lake & Yellow \\
& & herring & smelt & whitefish & perch \\
& $\left(\mu \mathrm{g} \cdot \mathrm{L}^{-1}\right)$ & present & Bythotrephes & & & &
\end{tabular}

\section{Reference}

$\begin{array}{lccccccc}\text { Buck } & 2.8 & 0 & 0 & \mathrm{~A} / \mathrm{P} & \mathrm{A} & \mathrm{A} & \mathrm{P} \\ \text { Doe } & 3.4 & 0 & 0 & \mathrm{~L} & \mathrm{~A} & \mathrm{~L} & \mathrm{P} \\ \text { Pickerel } & 4.4 & 0 & 0 & \mathrm{~L} & \mathrm{~A} / \mathrm{P} & \mathrm{A} & \mathrm{P} \\ \text { Sand } & 2.0 & 0 & 0 & \mathrm{~L} & \mathrm{H} & \mathrm{A} & \mathrm{P} \\ \text { Mean } & 3.1^{*} & 0 & 0 & & & & \end{array}$

Invaded

Kashaga-

wigamog

2

50

$\mathrm{M} / \mathrm{H}$

$\mathrm{L} / \mathrm{M}$

$\mathrm{A} / \mathrm{P}$

P

Skeleton

0.7

6

0

L $\quad$ L/M

M

$\mathrm{P}$ 


\begin{tabular}{|c|c|c|c|c|c|c|c|}
\hline Fairy & 2.2 & 7 & 0 & $\mathrm{~A} / \mathrm{P}$ & M & $\mathrm{A} / \mathrm{P}$ & $\mathrm{P}$ \\
\hline Mary & 2.5 & 8 & 0 & $\mathrm{~A} / \mathrm{P}$ & M & $\mathrm{L}$ & $\mathrm{P}$ \\
\hline $\begin{array}{l}\text { Lake } \\
\text { Muskoka }\end{array}$ & 2.9 & 8 & 1 & VL & $\mathrm{N} / \mathrm{A}$ & VL & $\mathrm{P}$ \\
\hline $\begin{array}{l}\text { Lake of } \\
\text { Bays }\end{array}$ & 1.7 & 7 & 1 & $\mathrm{~L} / \mathrm{M}$ & M & $\mathrm{M} / \mathrm{H}$ & $\mathrm{P}$ \\
\hline Harp & 1.7 & 7 & 2 & $\mathrm{H}$ & A & A & $\mathrm{P}$ \\
\hline Vernon & 2.8 & 7 & 4 & $\mathrm{~L}$ & M & $\mathrm{A} / \mathrm{P}$ & $\mathrm{P}$ \\
\hline Bernard & 2.8 & 7 & 2 & $\mathrm{~A} / \mathrm{P}$ & $\mathrm{L} / \mathrm{M}$ & $\mathrm{H}$ & $\mathrm{P}$ \\
\hline Peninsula & 2.6 & 8 & 6 & $\mathrm{~A} / \mathrm{P}$ & M & $\mathrm{A} / \mathrm{P}$ & $\mathrm{P}$ \\
\hline Mean & $2.2^{*}$ & 7 & 1.6 & & & & \\
\hline
\end{tabular}

594

$595 * p<0.05$

596 
597 Table 3. Multiple regression of crustacean zooplankton species richness with predictor variables

598 in all study lakes (invaded: $n=10$; reference: $n=4$ ). Persistence is defined as number of

599 consecutive sampling dates that Bythotrephes was $>5$ individuals $\cdot \mathrm{m}^{-3}$. AIC $=$ Akaike's

600 information criterion, $\mathrm{TP}=$ total phosphorus.

601

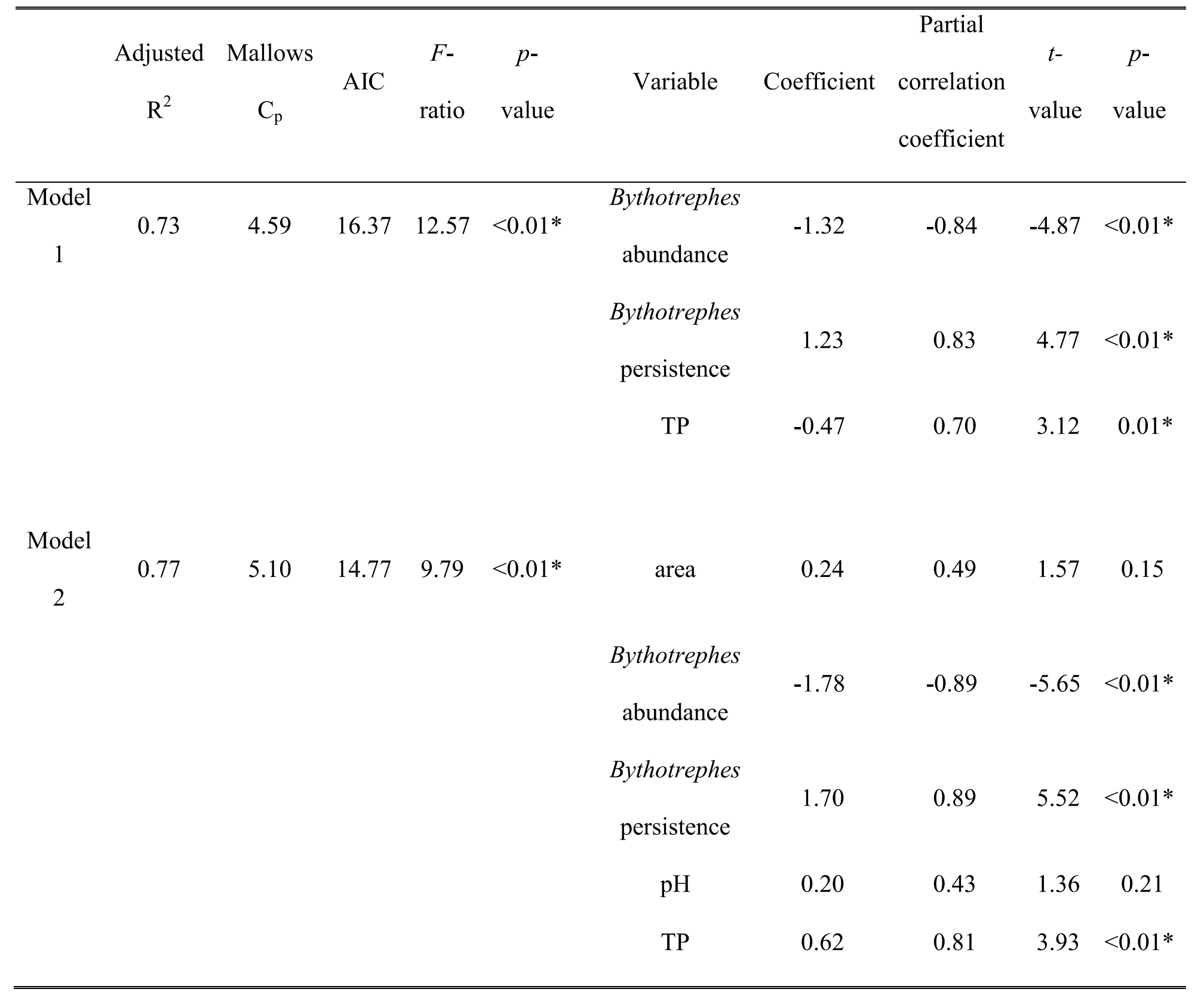

$602 * p<0.05$ 
603 Table 4. Summary of effects of Bythotrephes on several zooplankton community attributes in

604 different types of sampling regimes. Symbols indicate: + positive effect $(p<0.05)$; - negative

605 effect $(p<0.1) ;-$ negative effect $(p<0.05)$; 0 no effect.

\begin{tabular}{|c|c|c|c|c|}
\hline Variable & $\begin{array}{c}\text { Long-term } \\
\text { study } \\
\text { of Harp L. }{ }^{a, b}, \\
\text { Great Lakes }{ }^{c}\end{array}$ & $\begin{array}{l}\text { Synoptic } \\
\text { survey }^{d}\end{array}$ & $\begin{array}{l}\text { Seasonal } \\
\text { survey }^{e}\end{array}$ & $\begin{array}{c}\text { Field } \\
\text { experiment }^{f}\end{array}$ \\
\hline Richness & & & & \\
\hline total zooplankton & $-{ }^{a, c}$ & 一 & - & 0 \\
\hline cladocerans & $-^{a}$ & - & - & $0^{g}$ \\
\hline copepods & $0^{a}$ & 0 & 0 & $0^{g}$ \\
\hline
\end{tabular}

Abundance

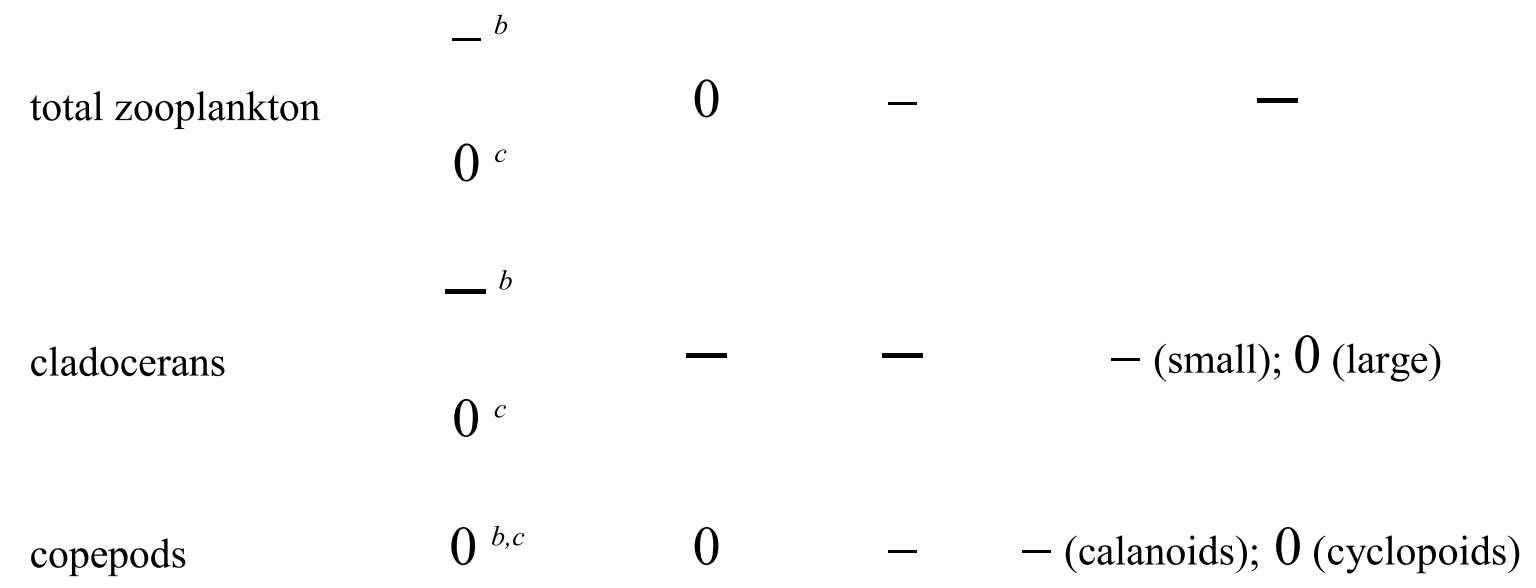

Diversity

$\begin{array}{lcccc}\text { total zooplankton } & \text { N/A } & \text { N/A } & 0 & 0 \\ \text { cladocerans } & \text { N/A } & \text { N/A } & - & 0^{g}\end{array}$


$\begin{array}{llll}\text { copepods } & \text { N/A } & \text { N/A } & 0\end{array}$ 606

$607{ }^{a}$ Yan et al. (2002); biweekly/monthly collections (1980-2000)

$608{ }^{b}$ Yan et al. (2001); biweekly/monthly collections (1980-1998)

$609{ }^{c}$ Barbiero and Tuchman (2004); multiple stations in Lakes Michigan, Huron, and Erie

610 (1983-1999)

$611{ }^{d}$ Boudreau and Yan (2003); single mid-summer sampling date (2001)

$612^{e}$ this study

$613{ }^{f}$ Strecker and Arnott (2005); 30 day enclosure experiment

$614{ }^{g}$ A. Strecker, unpubl. data

615 


\section{Figure Captions}

617 Figure 1. Box-and-whisker plots of (a) species richness, (b) Shannon-Wiener diversity, (c) $E_{\text {var, }}$

618 and (d) abundance (individuals $\cdot \mathrm{m}^{-3}$ ) for total crustacean zooplankton, cladocerans, and copepods

619 in invaded (white boxes; $n=10$ ) and reference lakes (grey boxes; $n=4$ ). The centre is the mean,

620 the box is the standard error, the whiskers are the standard deviation, and the asterisk ( $\star$ ) is $p<$

6210.05.

622

623 Figure 2. On the left axis, percent change in invaded lakes richness (white bars) and abundance

624 (grey bars) from the average of the reference lakes, contrasted with mean Bythotrephes

625 abundance $\left(\bullet\right.$; individuals $\left.\cdot \mathrm{m}^{-3}\right)$ on the right axis. Vertical error bars represent \pm standard error.

626 Lake names: BERN = Bernard, $\mathrm{KASH}=$ Kashagawigamog, LOB $=$ Lake of Bays, MUSK =

627 Lake Muskoka, PEN $=$ Peninsula, $\mathrm{SKEL}=$ Skeleton, $\mathrm{VERN}=$ Vernon.

629 Figure 3. Redundancy analysis of zooplankton species abundances and environmental

630 conditions. Environmental variables are represented by the large arrows and species by the small

631 arrows. Species with short arrows were removed to reduce crowding. Circles are site scores for

632 invaded $(\bigcirc)$ and reference $(\mathrm{O})$ lakes. Species names are italicized. Lake names: BERN =

633 Bernard, KASH $=$ Kashagawigamog, $\mathrm{LOB}=$ Lake of Bays, MUSK $=$ Lake Muskoka, $\mathrm{PEN}=$

634 Peninsula, $\mathrm{PICK}=$ Pickerel, $\mathrm{SKEL}=$ Skeleton, $\mathrm{VERN}=$ Vernon. Environmental variables: $\mathrm{TP}=$ 635 total phosphorus, $\mathrm{Z}_{\max }=$ maximum depth, chl $a=$ chlorophyll $a$.

637 Figure 4. Mean abundance (individuals $\cdot \mathrm{m}^{-3}$ ) of (a) calanoid $(\diamond)$ and cyclopoid $(\mathbf{\Delta})$ copepods

638 and (b) large $(\mathbf{\square} ;>1 \mathrm{~mm})$ and small $(\mathrm{O} ;<1 \mathrm{~mm})$ cladocerans in reference lakes plotted against 639 corresponding abundance in invaded lakes. Abbreviations of zooplankton taxa are (a) Aca rob= 640 Acanthocyclops robustus, cal naup = calanoid nauplii, cyc naup = cyclopoid nauplii, $C y c s c u=$ 
641 Cyclops scutifer, Dia bic th = Diacyclops bicuspidatus thomasi, Epi lac = Epischura lacustris,

642 Lep ash = Leptodiaptomus ashlandi, Lep min = Leptodiaptomus minutus, Lep sic =

643 Leptodiaptomus sicilis, Mes edax = Mesocyclops edax, Ort mod = Orthocyclops modestus, Sen

$644 c a l=$ Senecella calanoides, Ski ore $=$ Skistodiaptomus oregonensis, Tro ext $=$ Tropocyclops

645 extensus; and (b) Acr har = Acroperus harpae, Bosm = Bosmina (Bosmina) spp., Chyd =

646 Chydorus spp., Dap amb = Daphnia ambigua, Dap cat = Daphnia catawba, Dap dub =

647 Daphnia dubia, Dap lon = Daphnia longiremis, Dap men = Daphnia mendotae, Dap ret =

648 Daphnia retrocurva, Dia bir = Diaphanosoma birgei, Eub cor = Eubosmina coregoni, Eub tub

$649=$ Eubosmina tubicen, Hol gib $=$ Holopedium gibberum, Lat set $=$ Latona setifera, Lep kin $=$

650 Leptodora kindtii, Pol ped = Polyphemus pediculus, Sid cry = Sida crystallina. 
652 Table S1. Zooplankton species presence/absence in study lakes. Taxonomic authorities in

653 parentheses indicate genus name has changed since original description. $*=$ invaded lakes

\begin{tabular}{|c|c|c|c|c|c|}
\hline Species & Authority & Bernard* & Buck & Doe & Fairy* \\
\hline Acanthocyclops robustus $^{a}$ & (Sars) & & & $\mathrm{x}$ & \\
\hline Acroperus harpae & (Baird) & & $\mathrm{x}$ & & \\
\hline Bosmina (Bosmina) & De Melo and & & & & \\
\hline liederi/freyi ${ }^{b}$ & Hebert & $\mathrm{x}$ & $\mathrm{x}$ & $\mathrm{x}$ & $\mathrm{x}$ \\
\hline Chydorus & O.F. Müller/ & & & & \\
\hline sphaericus/brevilabris & Frey & & & $\mathrm{x}$ & \\
\hline Cyclops scutifer & Sars & $\mathrm{x}$ & & & \\
\hline Daphnia (Daphnia) ambigua & Scourfield & & $\mathrm{x}$ & $\mathrm{x}$ & \\
\hline Daphnia (Daphnia) catawba & Coker & & & & \\
\hline Daphnia (Daphnia) retrocurva & Forbes & & $\mathrm{x}$ & & \\
\hline Daphnia (Hyalodaphnia) dubia & Herrick & & & & \\
\hline Daphnia (Hyalodaphnia) longiremis & Sars & & $\mathrm{x}$ & $\mathrm{x}$ & $\mathrm{x}$ \\
\hline Daphnia (Hyalodaphnia) mendotae ${ }^{c}$ & Birge & & $\mathrm{x}$ & $\mathrm{x}$ & $\mathrm{x}$ \\
\hline Diacyclops bicuspidatus thomasi & (Forbes) & $\mathrm{x}$ & $\mathrm{x}$ & $\mathrm{x}$ & $\mathrm{x}$ \\
\hline Diaphanosoma birgei & Korrínek & & $\mathrm{x}$ & $\mathrm{x}$ & $\mathrm{x}$ \\
\hline Epischura lacustris & Forbes & $\mathrm{x}$ & $\mathrm{x}$ & $\mathrm{x}$ & $\mathrm{x}$ \\
\hline Eubosmina (Eubosmina) coregoni ${ }^{d}$ & (Baird) & & & & \\
\hline Eubosmina (Neobosmina) tubicen ${ }^{e}$ & (Brehm) & & & $\mathrm{x}$ & \\
\hline
\end{tabular}


Holopedium gibberum

Latona setifera

Leptodiaptomus ashlandi

Leptodiaptomus minutus

Leptodiaptomus sicilis

Leptodora kindtii

Mesocyclops edax

Orthocyclops modestus

Polyphemus pediculus

Senecella calanoides

Sida crystallina

Skistodiaptomus oregonensis

Tropocyclops extensus ${ }^{f}$
Zaddach

(O.F. Müller)

(Marsh)

(Lilljeborg)

(Forbes)

(Focke)

(Forbes)

(Herrick)

(Linnaeus)

Juday

(O.F. Müller)

(Lilljeborg)

(Kiefer)

X $\quad$ X 


\begin{tabular}{lllll}
\hline \hline \multirow{2}{*}{ Species } & Kashaga- & Lake & Lake of \\
& Harp* & Mary* \\
& & wigamog* & Muskoka* \\
& & & Bays*
\end{tabular}

Acanthocyclops robustus $^{a}$

Acroperus harpae

Bosmina (Bosmina) liederi/freyi ${ }^{b}$

$\mathrm{X}$

$\mathrm{x}$

$\mathrm{X}$

$\mathrm{X}$

Chydorus sphaericus/brevilabris

$\mathrm{X}$

Cyclops scutifer

$\mathrm{X}$

Daphnia (Daphnia) ambigua

Daphnia (Daphnia) catawba

Daphnia (Daphnia) retrocurva

$\mathrm{X}$

Daphnia (Hyalodaphnia) dubia x

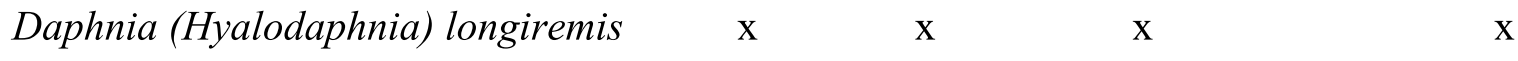

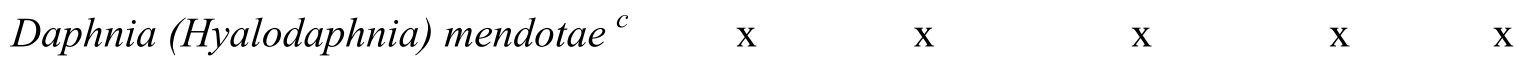

$\begin{array}{lllllll}\text { Diacyclops bicuspidatus thomasi } & \mathrm{x} & \mathrm{x} & \mathrm{x} & \mathrm{x} & \mathrm{x}\end{array}$

Diaphanosoma birgei $\quad$ x $\quad$ x

$\begin{array}{llllll}\text { Epischura lacustris } & \text { X } & \text { X } & \text { x } & \text { X } & \text { x }\end{array}$

Eubosmina (Eubosmina) coregoni ${ }^{d}$

Eubosmina (Neobosmina) tubicen ${ }^{e}$

666

667

668 
Holopedium gibberum

X

$\mathrm{X}$

X

X

$\mathrm{X}$

Latona setifera

Leptodiaptomus ashlandi

Leptodiaptomus minutus

X

$\mathrm{X}$

X

X

$\mathrm{X}$

Leptodiaptomus sicilis

$\mathrm{X}$

X

X

$\mathrm{X}$

Leptodora kindtii

$\mathrm{X}$

Mesocyclops edax

$\mathrm{X}$

$\mathrm{X}$

Orthocyclops modestus

$\mathrm{X}$

$\mathrm{X}$

$\mathrm{X}$

Polyphemus pediculus

$\mathrm{x}$

Senecella calanoides

X

$\mathrm{x}$

X

Sida crystallina

$\mathbf{X}$

$\mathbf{X}$

Skistodiaptomus oregonensis

Tropocyclops extensus ${ }^{f}$

$\mathrm{X}$

669

$670{ }^{a}$ formerly Acanthocyclops vernalis complex

$67 b^{b}$ formerly Bosmina (Sinobosmina) spp.

$672{ }^{c}$ formerly Daphnia galeata mendotae

$673{ }^{d}$ formerly Bosmina (Eubosmina) coregoni

$674{ }^{e}$ formerly Bosmina (Neobosmina) tubicen

$675{ }^{f}$ formerly Tropocyclops prasinus mexicanus

676

677 


Species $\quad$ Peninsula* Pickerel Sand Skeleton* Vernon*

\begin{tabular}{lll}
\hline Acanthocyclops robustus $^{a}$ & $\mathrm{x}$
\end{tabular}

Acroperus harpae

Bosmina (Bosmina) liederi/freyi ${ }^{b}$

$\mathrm{X}$

$\mathrm{X}$

$\mathbf{X}$

$\mathbf{X}$

$\mathbf{X}$

Chydorus sphaericus/brevilabris

$\mathbf{X}$

X

Cyclops scutifer

$\mathrm{X}$

X

Daphnia (Daphnia) ambigua

$\mathrm{X}$

$\mathrm{X}$

Daphnia (Daphnia) catawba

$\mathrm{X}$

$\mathrm{X}$

Daphnia (Daphnia) retrocurva

$\mathbf{X}$

Daphnia (Hyalodaphnia) dubia x

Daphnia (Hyalodaphnia) longiremis $\quad \mathrm{x}$

$\mathrm{X} \quad \mathrm{X}$

Daphnia (Hyalodaphnia) mendotae ${ }^{c} \quad \mathrm{x}$

$\begin{array}{lllll}\text { X } & \mathrm{X} & \mathrm{X} & \mathrm{X}\end{array}$

Diacyclops bicuspidatus thomasi

$\mathrm{X}$

$\mathbf{X}$

$\mathbf{X}$

$\mathrm{X}$

$\mathbf{X}$

Diaphanosoma birgei

$\mathrm{X}$

$\mathrm{X}$

Epischura lacustris

$\mathbf{X}$

$\mathbf{X}$

$\mathrm{X}$

Eubosmina (Eubosmina) coregoni $^{d} \quad \mathrm{x}$

Eubosmina (Neobosmina) tubicen $^{e} \quad \mathrm{x} \quad \mathrm{x} \quad \mathrm{x} \quad \mathrm{x}$ 
Holopedium gibberum

Latona setifera

Leptodiaptomus ashlandi

Leptodiaptomus minutus

Leptodiaptomus sicilis

Leptodora kindtii

Mesocyclops edax

Orthocyclops modestus

Polyphemus pediculus

Senecella calanoides

Sida crystallina

Skistodiaptomus oregonensis

$\mathrm{X}$

$\mathrm{X}$

$\mathrm{x}$

x

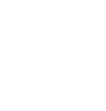

$\mathrm{X}$

$\mathrm{X}$

$\mathrm{X}$

$\mathrm{X}$

$\mathrm{X}$

$\mathrm{X}$

$\mathrm{X}$

$\mathrm{X}$

Tropocyclops extensus ${ }^{f}$

$681{ }^{a}$ formerly Acanthocyclops vernalis complex

$682{ }^{b}$ formerly Bosmina (Sinobosmina) spp.

$683^{c}$ formerly Daphnia galeata mendotae

$684^{d}$ formerly Bosmina (Eubosmina) coregoni

$685^{e}$ formerly Bosmina (Neobosmina) tubicen

$686{ }^{f}$ formerly Tropocyclops prasinus mexicanus

687

688

689 


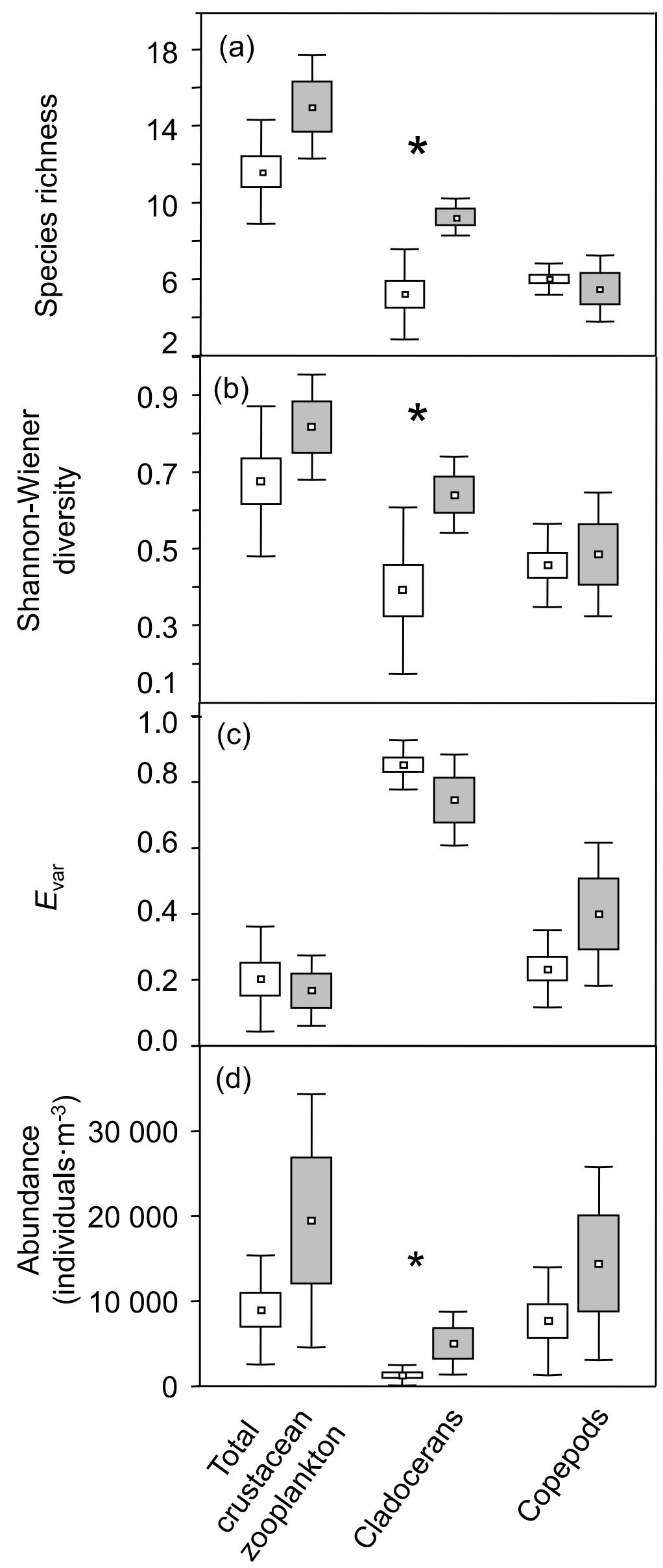

Figure 1. 


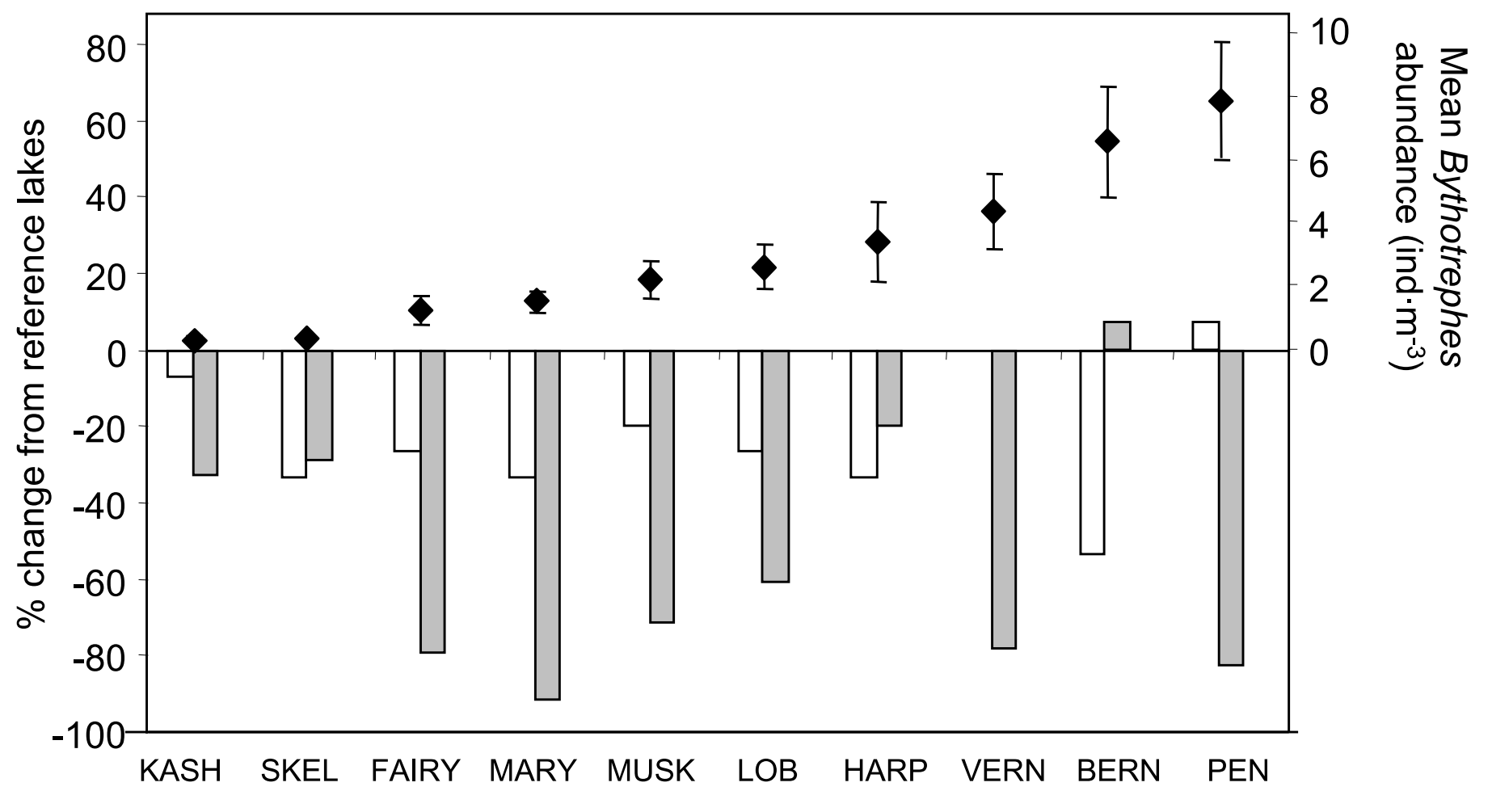

Lake

Figure 2. 


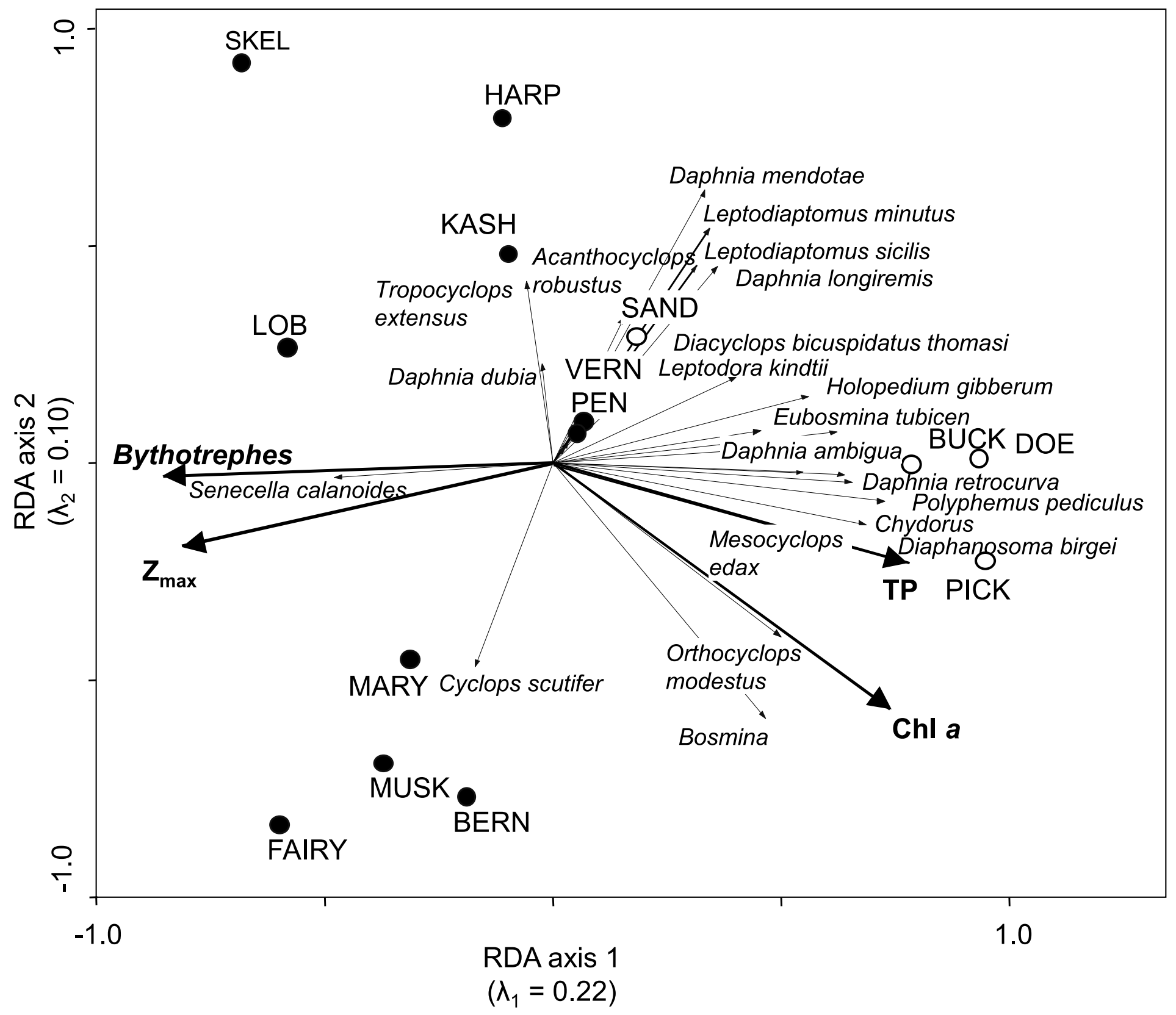

Figure 3. 


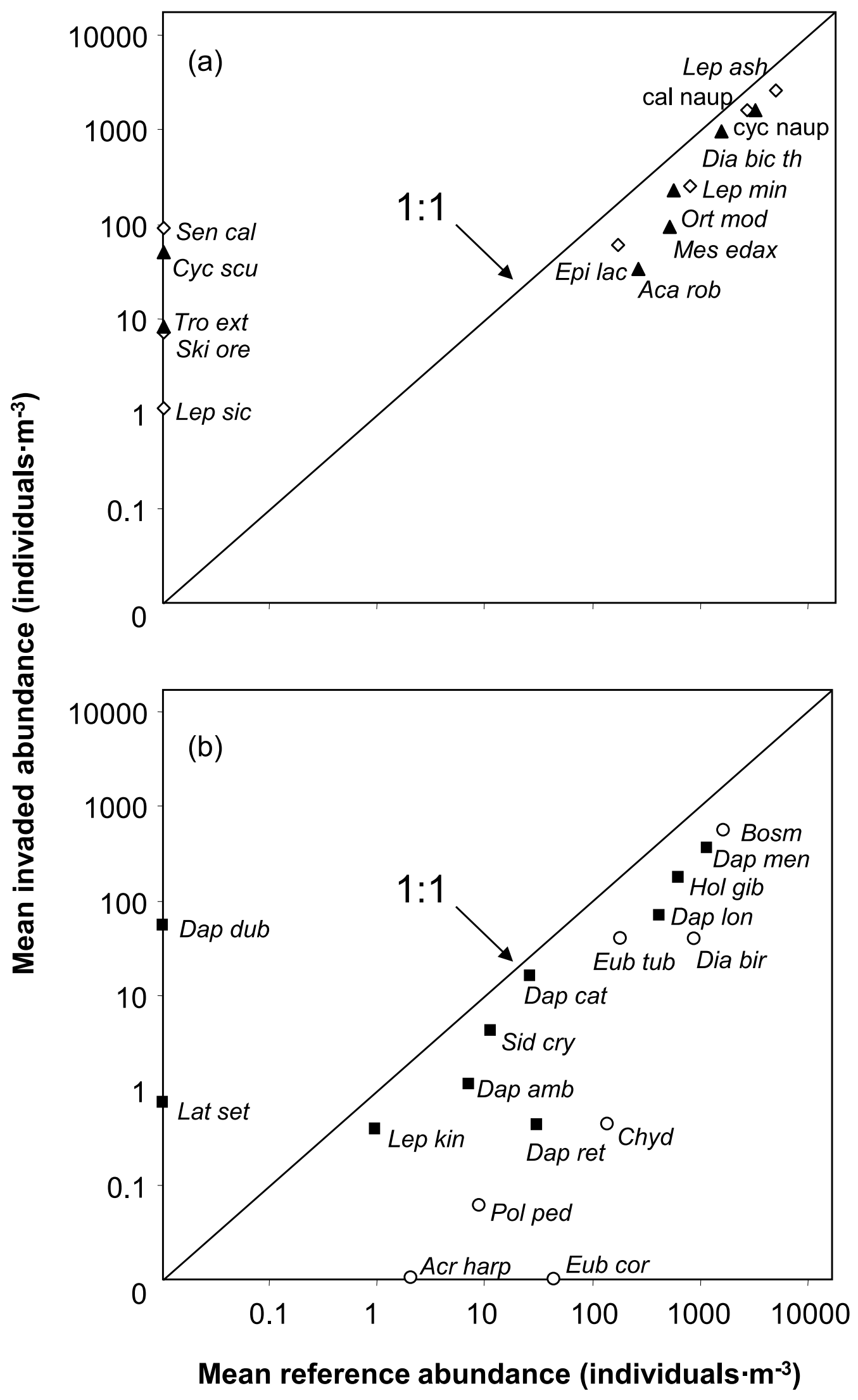

Figure 4. 